\title{
Evaluation of Corona Virus Disease-19 Related Fear and Anxiety in Patients Admitted to Neurology Outpatient Clinic
}

\author{
Nöroloji Polikliniğine Başvuran Hastalarda Korona Virus Hastaliği-19 İlişkili Korku ve Anksiyetenin Değerlendirilmesi
}

University of Health Science, İzmir Bozyaka Training and Research Hospital, Department of Neurology,

İzmir Turkey

Correspondence: Neslihan ESKUT

University of Health Science, İzmir Bozyaka Training and Research Hospital, Department of Neurology, İzmir Turkey

e-mail: nespur@hotmail.com

\section{Neslihan Eskut, Ceyla Atac, Asli Koskderelioglu, Yaprak Ozum Unsal Bilgin}

\section{Abstract}

SARS-CoV-2, quickly spread and became a threat to public health. The majority of the people are affected psychologically, socially, economically by the pandemic. We aimed to investigate the level of anxiety and fear about coronavirus disease 19 (COVID-19) and related factors in patients with chronic neurological disease We evaluated the patients with chronic neurological disease who have been followed up at our outpatient clinic before the pandemic. Demographical data, information about social media use, change of hospital admission during the pandemic and status of the patients' or family members' whether they had the COVID-19 disease were recorded. We investigated the fear of COVID-19 and coronavirus anxiety of the study population with Fear of COVID-19 and The Coronavirus Anxiety Scale. The study population was consisted of 247 patients (158 women, 89 men). The distribution of the patient groups was as follow: $28.34 \%$ headache, $12.5 \%$ stroke, $5.6 \%$ Parkinson's disease, multiple sclerosis $34.8 \%$, epilepsy $13.36 \%$, others $5.26 \%$. Mean scores of FC-19 S, CAS of the study group were $18 \pm 6.76$ and $1.31 \pm 2.42$, respectively. There was no statically significant difference in the FC-19 S and CAS scores between chronic neurological disease groups ( $p>0.05$ ) but females reported higher FC-19 S scores $(p=0.001)$. Rate of social media users was $67.6 \%$ and $45.67 \%$ of the patients reported that they were affected by the COVID-19 related news. Often enough, communication with chronic disease patients by healthcare professionals is a key to the patients to be adherence to the medications and follow up visits. During the pandemic, the health system needs new solutions. We think that legal regulations regarding using technological tools such as telemedicine and video consultancy should be completed in our country.

Keywords: Chronic neurological disease; pandemic; coronavirus; fear; anxiety,

\section{Özet}

SARS-CoV-2, hızla yayıldı ve halk sağlığı için tehdit oluşturdu. İnsanların çoğu pandemiden psikolojik, sosyal ve ekonomik olarak etkilendi. Bu çalışmada, kronik nörolojik hastalığı olan hastalarda Koronavirüs 19 hastalığı (COVID-19) ilişkili anksiyete ve korku seviyesini araștırmayı amaçladık. Pandemi öncesinde polikliniğimizde takipte olan, kronik nörolojik hastalığı olan hastaları değerlendirdik. Demografik bilgiler, sosyal media kullanım bilgisi, pandemide hastaneye başvurularındaki değişim ve kendisinin ya da ailesinin COVID-19 geçirip geçirmedikleri kaydedildi. COVID-19 korku ve anksiyetesi; COVID-19 korku ölçeği (FC-19 S), Koronavirisanksiyete ölçeği (CAS) ile araștırıldı. Çalıșma popülasyonu 247 hastadan (158 kadın, 89 erkek) oluşmaktadır. Hasta gruplarının dağılımı; \%28,34 migren, \% 12,5 inme, \% 5,6 Parkinson hastalığı, \% 34,8 Multipl sclerosis, \% 13,36 epilepsi, \%5,26 diğer șekildeydi. Ortalama FC-19 S, CAS skorları sırasıyla $18 \pm 6,76$ ve $1,31 \pm 2,42$ idi. Grupların FC-19 S and CAS skorları arasında anlamlı fark saptanmadı ( $\mathrm{p}>0.05$ ) fakat kadınların FC-19 S skorları yüksekti ( $\mathrm{p}=0,001$ ). Sosyal media kullanım oranı \% 67,6' ydi ve hastaların \% 45,67’ si COVID-19 ilişkili haberlerden etkilendiklerini belirttiler. Kronik hastalığı olanların sağlık profesyonelleriyle yeterli sıklıkta iletișim kurması hastaların ilaç uyumu ve izlem kontrolleri için anahtardır. Pandemi döneminde sağlık sisteminin yeniç özümlere ihtiyacı vardır. Ülkemizde teletıp, video konsültasyon gibi teknolojik araçların kullanımına ilişkin gerekli yasal düzenlemelerin tamamlanması gerektiğini düşünüyoruz.

Anahtar Kelimeler: Kronik nörolojik hastalık; pandemi, koronavirüs; korku; anksiyete 


\section{Introduction}

Severe acute respiratory syndrome coronavirus-2 (SARS-CoV-2), a novel strain of coronavirus, quickly spread worldwide and became a real threat to public health. SARSCoV-2 was reported as the causative agent of coronavirus disease 2019 (COVID-19) (1). The World Health Organization (WHO) indicated that COVID-19 was an outbreak to be concerned about on 30th January 2020 and then declared the pandemic on 11th March (2). The first reported COVID-19 case in Turkey was on 10th March 2020. According to Ministry of Health of Turkish Republic data, COVID-19 resulted in more than 30.000 deaths in Turkey (3).

Since December 2019, memorable days have been experiencing all over the world. The majority of the people are affected psychologically, socially, economically because of the pandemic (4). Traumatic stress disorder, anxiety, and depression are reported as psychological effects of pandemics (5). Governments implemented different quarantine policies for limiting the free movement of people, canceled or limited all the activities considered not essential, so the pandemic is tried to be brought under control. In Turkey, according to the Governments' decisions, the rules to be followed in all areas of daily life are updated periodically by the science board of the Ministry of Health (6).

Likewise, rules of outpatient clinic, invasive and non-invasive procedures have been changed in all medical specialties during the pandemic (7). It is reported that neurological diseases seem to be independently associated with a severe form of COVID-19 (8). Most patients with neurological diseases could be affected by other comorbid diseases, older and fragile, or using medication related to the immune system (9). Because of the reasons mentioned before, most patients with neurological diseases can be thought to be at high risk for severe COVID-19 (10). Although some changes were made in the operation of our hospitals' outpatient clinics due to the pandemic, patient admission has been continued. However, as infection and mortality rates increased related to COVID-
19 , this caused widespread fear and anxiety $(11,12)$.

We aimed to investigate the prevalence of anxiety and level of fear about COVID-19 and related factors in patients with chronic neurological disease during the COVID-19 pandemic.

\section{Material and Methods}

The study was carried out at the University of Health Sciences, İzmir Bozyaka Training and Research Hospital, Neurology outpatient clinic, between October and February 2020. We evaluated the patients admitted to the neurology outpatient clinic and patients with chronic neurological disease (such as multiple sclerosis, epilepsy, migraine, cerebrovascular disease, Parkinson's disease, neuromuscular disorders, dementia) who have been followed up at our outpatient clinic before the pandemic were included the study. Patients who applied to our outpatient clinic for the first time or were not diagnosed with one of the chronic neurological diseases were excluded. We also excluded the patients with the diagnosis of depression or using antidepressants. We consecutively evaluated 310 patients with chronic neurological disease. However, 62 of 310 patients were excluded because the previous follow-up period was performed in another hospital or a new diagnosis was made.

Patients information, including age, sex, education year, duration of the disease, information about social media usage, change of hospital admission during the pandemic, and change of these patients' course of the disease and status of the patients' or family members' whether had the COVID-19 disease were recorded. In the study, we asked how they were affected by the COVID-19 related news. We investigated the Fear of COVID-19 and coronavirus anxiety of the study population with the following tools. 


\section{Fear of COVID-19 Scale (FC-19 S)}

We used the Turkish version of the Fear of COVID-19 Scale (FC-19S) to evaluate the fear of COVID- 19. FC-19 S was developed by Ahorsu et al. (11) and adapted to Turkish by Bakioğlu et al and Satıcı et al. $(13,14)$. The scale consists of 7 items. Each item has a fivepoint Likert scale (1: Strongly disagree, 5: Strongly agree). Cronbach's alpha internal consistency coefficient of the original and Turkish versions was 0.82 and 0.88 , respectively.

\section{The Coronavirus Anxiety Scale (CAS)}

We used the Turkish version of the Coronavirus Anxiety Scale (CAS) to evaluate the anxiety related to COVID-19. CAS was developed by Lee (15) and adapted to Turkish by Evren et al and Biçer et al (16-18). The scale consists of 5 items. Lee reported that the CAS discriminates between dysfunctional anxiety and non-anxiety with an optimized cut-off score of 9 (90\% sensitivity and $85 \%$ specificity) (15). Each item of the questionnaire is designed as a five-point to question the anxiety status in the last two weeks ( 0 : never; 1: rare, less than one day or two; 2: several days; 3: more than seven days; 4: in the last two weeks almost every day.

\section{Ethical approval}

Local Ethical Committee of İzmir Bozyaka Training and Research Hospital (Ethical approval license: Reference Number: 05 Date: 13/01/2021) and the Turkey Ministry of Health Scientific Research Platform approved (2021-01-06T22_08_10) the study protocol. Informed consent was obtained from all participants. We conducted the study according to the principles of the Declaration of Helsinki.

\section{Statistical Analysis}

Statistical analysis of obtained data was performed using the SPSS 24.0 package program (IBM Corp .; Armonk, NY, USA). The normal distribution of the data was analyzed by examining the One Sample Kolmogrov-Smirnov test Continuous variables were given as mean \pm S.D. Categorical variables were expressed as percentages. Student t-test was used for parametric data to compare continuous variables, and MannWhitney U testswereusedfornonparametric data comparison. All tests were considered significant at $p<0.05$. The Oneway ANOVA test was used to compare more than two groups, and then the analysis was performed with the Tukey test. The relationship between disease duration, FC-19 S and CASscores was evaluated using Spearman correlation analysis. Data analyzed at $95 \%$ confidence interval and all tests were considered significant at $\mathrm{p}<0.05$

\section{Results}

The Study population was consisted of 247 patients with chronic neurological disease. One hundred fifty-eight women (63.9\%), 89 men $(36.1 \%)$ were included in the study. The mean age of the patients was $45.95 \pm 16.09$. $77.73 \%$ of the participants were married. The distribution of the patient groups of chronic neurological disease was as follow: $28.34 \%$ migraine, $12.5 \%$ stroke, 5.6\% Parkinson's disease, multiple sclerosis $34.8 \%$, epilepsy $13.36 \%$, others (myasthenia gravis, carpal tunnel syndrome, mild cognitive impairment, obstructive sleep apnea, restless legs syndrome) $5.26 \%$. $27.93 \%$ of the participants had at least one more comorbid disease. Mean scores of FC-19 S, CAS of the study group were $18 \pm 6.76$ and $1.31 \pm 2.42$, respectively. There was no statically significant difference in the FC-19 S and CAS scores between chronic neurological disease groups ( $p>0.05)$. $75.3 \%$ of the participants reported that their selves / a family member or someone from close circles had COVID-19. FC-19 S scores of this group of participants were significantly higher than others (p: 0.003). We compared the scores of FC-19 S and CAS in males and females. While there was no statically significant difference between the CAS scores according to sex, females reported higher FC19 S scores $(p=0.001)$. Similarly, while no statically significant difference was found according to marital status in the CAS scores, married individuals reported higher FC-19 S scores $(p=0.02)$. In our study group, which consists of patients who had a chronic neurological disease, it was found that the presence of the other comorbid disease did not 
cause a significant difference in FC-19 S or CAS scores $(p=0.68)$. In addition, when we evaluated the FC-19 S scores according to age, higher scores were obtained in participants under the age of 65 . But it was not statically significant $(\mathrm{p}>0.05)$. There was no significant relationship between FC-19 S and CAS scores with age, education level, the status of social media use, and had the type of chronic neurological disease. The statistical comparisons of the study groups' sociodemographic characteristics with FC-19 $\mathrm{S}$ and CAS were presented in Table 1.

Table 1: Clinical and sociodemographic characteristics of the patients

\begin{tabular}{|c|c|c|c|c|c|}
\hline & $\begin{array}{l}\text { Total } \\
\mathbf{n}=\mathbf{2 4 7}\end{array}$ & $\begin{array}{l}\text { Fear of COVID-19 scale, } \\
\text { Mean } \pm \text { SD }\end{array}$ & $\mathbf{p}$ & $\begin{array}{l}\text { Coronavirus Anxiety } \\
\text { ScaleMean } \pm \text { SD }\end{array}$ & $\mathbf{p}$ \\
\hline $\begin{array}{l}\text { Sex, n (\%) } \\
\text { - Female } \\
\text { - Male }\end{array}$ & $\begin{array}{l}158(64) \\
89(36)\end{array}$ & $\begin{array}{l}19.11 \pm 6.77 \\
16.03 \pm 6.33\end{array}$ & 0,001 & $\begin{array}{l}1.41 \pm 2.50 \\
1.12 \pm 2.27\end{array}$ & 0.19 \\
\hline Age, $\operatorname{mean} \pm$ SD & $45.95 \pm 16.09$ & & & & \\
\hline $\begin{array}{l}\cdot \geq 65 \\
\cdot<65\end{array}$ & $\begin{array}{l}74.05 \pm 7.08 \\
40.84 \pm 11.26\end{array}$ & $\begin{array}{l}16.52 \pm 6.04 \\
18.27 \pm 6.87\end{array}$ & 0.12 & $\begin{array}{l}1.13 \pm 1.94 \\
1.34 \pm 2.49\end{array}$ & 0.61 \\
\hline $\begin{array}{l}\text { Duration of thedisease } \\
\text { (year),,mean } \pm \text { SD }\end{array}$ & $7.66 \pm 7.93$ & $18.00 \pm 6.76$ & 0.51 & $1.31 \pm 2.42$ & 0.98 \\
\hline $\begin{array}{l}\text { MaritalStatus, n (\%) } \\
\text { - Married } \\
\text { - Single }\end{array}$ & $\begin{array}{r}192(77.7) \\
55(22.3)\end{array}$ & $\begin{array}{l}18.52 \pm 6.84 \\
16.20 \pm 6.21\end{array}$ & 0.02 & $\begin{array}{l}1.27 \pm 2.43 \\
1.43 \pm 2.38\end{array}$ & 0.55 \\
\hline $\begin{array}{l}\text { Education Level (year), n (\%) } \\
\cdot \leq 8 \\
\cdot 12 \\
\cdot 16\end{array}$ & $\begin{array}{r}158(64) \\
57(23) \\
32(13)\end{array}$ & $\begin{array}{l}17.93 \pm 6.77 \\
18.12 \pm 6.91 \\
18.62 \pm 7.06\end{array}$ & 0.87 & $\begin{array}{l}1.40 \pm 2.39 \\
0.80 \pm 1.64 \\
1.71 \pm 3.45\end{array}$ & 0.16 \\
\hline $\begin{array}{l}\text { UseSocial Media, n (\%) } \\
\text { - User } \\
\text { •Non-user }\end{array}$ & $\begin{array}{r}167(67.6) \\
80(32.4)\end{array}$ & $\begin{array}{l}18.28 \pm 7.03 \\
17.42 \pm 6.18\end{array}$ & 0.44 & $\begin{array}{l}1.36 \pm 2.63 \\
1.20 \pm 1.91\end{array}$ & 0.26 \\
\hline $\begin{array}{l}\text { Presence of Co-morbiddisease, } \\
\text { n }(\%) \\
\cdot \text { Yes } \\
\text { - No }\end{array}$ & $\begin{array}{l}69(27.9) \\
178(72.1)\end{array}$ & $\begin{array}{l}18.28 \pm 7.03 \\
17.89 \pm 6.68\end{array}$ & 0.68 & $\begin{array}{l}1.65 \pm 2.83 \\
1.17 \pm 2.23\end{array}$ & 0.14 \\
\hline $\begin{array}{l}\text { COVID-19 status*, n (\%) } \\
\cdot \text { Yes } \\
\cdot \text { No }\end{array}$ & $\begin{array}{r}151(61.2) \\
96(38.8)\end{array}$ & $\begin{array}{l}18.91 \pm 6.29 \\
17.11 \pm 7.11\end{array}$ & 0.03 & $\begin{array}{l}1.43 \pm 2.30 \\
1,19 \pm 2.53\end{array}$ & 0.13 \\
\hline $\begin{array}{l}\text { Diagnosis, n (\%) } \\
\text { - Migraine } \\
\text { - Epilepsy } \\
\text { - Stroke } \\
\text { - MultipleSklerosis } \\
\text { - Parkinson'sDisease } \\
\text { - Others }\end{array}$ & $\begin{array}{l}70(28.3) \\
33(13.4) \\
31(12.6) \\
86(34.8) \\
14(5.7) \\
13(5.3)\end{array}$ & $\begin{array}{l}18.98 \pm 6.79 \\
17.75 \pm 7.07 \\
18.03 \pm 6.54 \\
16.95 \pm 7.13 \\
19.85 \pm 4.58 \\
18.23 \pm 568\end{array}$ & 0.46 & $\begin{array}{l}0.94 \pm 1.35 \\
1.15 \pm 2.65 \\
0.96 \pm 1.95 \\
\\
1.77 \pm 3.08 \\
1.07 \pm 1.38 \\
1.69 \pm 2.95\end{array}$ & 0.30 \\
\hline
\end{tabular}

\footnotetext{
*Their selves / a family member or someone from close circles had COVID-19
}

In the gender subgroup analysis, the sociodemographic characteristics of the patients were compared with the FC-19 S. In patients $>65$ years of age $(p=0.02)$ and patients with disease duration $(\mathrm{p}=0.02$, $\mathrm{r}=0.18$ ), mean scores of FC-19 $\mathrm{S}$ were significantly higher in females. There was a weak correlation between disease duration and FC-19 S scores. Again, there was a significant relationship between education levels and CAS scores in women $(p=0.005)$. In the post-hoc (Tukey) test evaluation between education levels, CAS scores were significantly higher in university graduates than high school graduates in females $(p=0.005)$. Mean scores of FC-19 S $(p=0.002)$ 
and CAS ( $\mathrm{p}=0.01$ ) were significantly higher in males with one more comorbid disease. There was a significant correlation between FC-19 S scores in comparison of disease subgroups in men $(p=0.02)$. In the post-hoc (Tukey) test, FC-19 S scores of patients with Parkinson's disease were significantly higher than patients with migraine in men $(p=0.04)$. The statistical comparisons of the study groups' sociodemographic characteristics according to gender were presented in Table 2 .

Table 2: Gender sub group analysis of clinical and sociodemographic characteristics of the patients

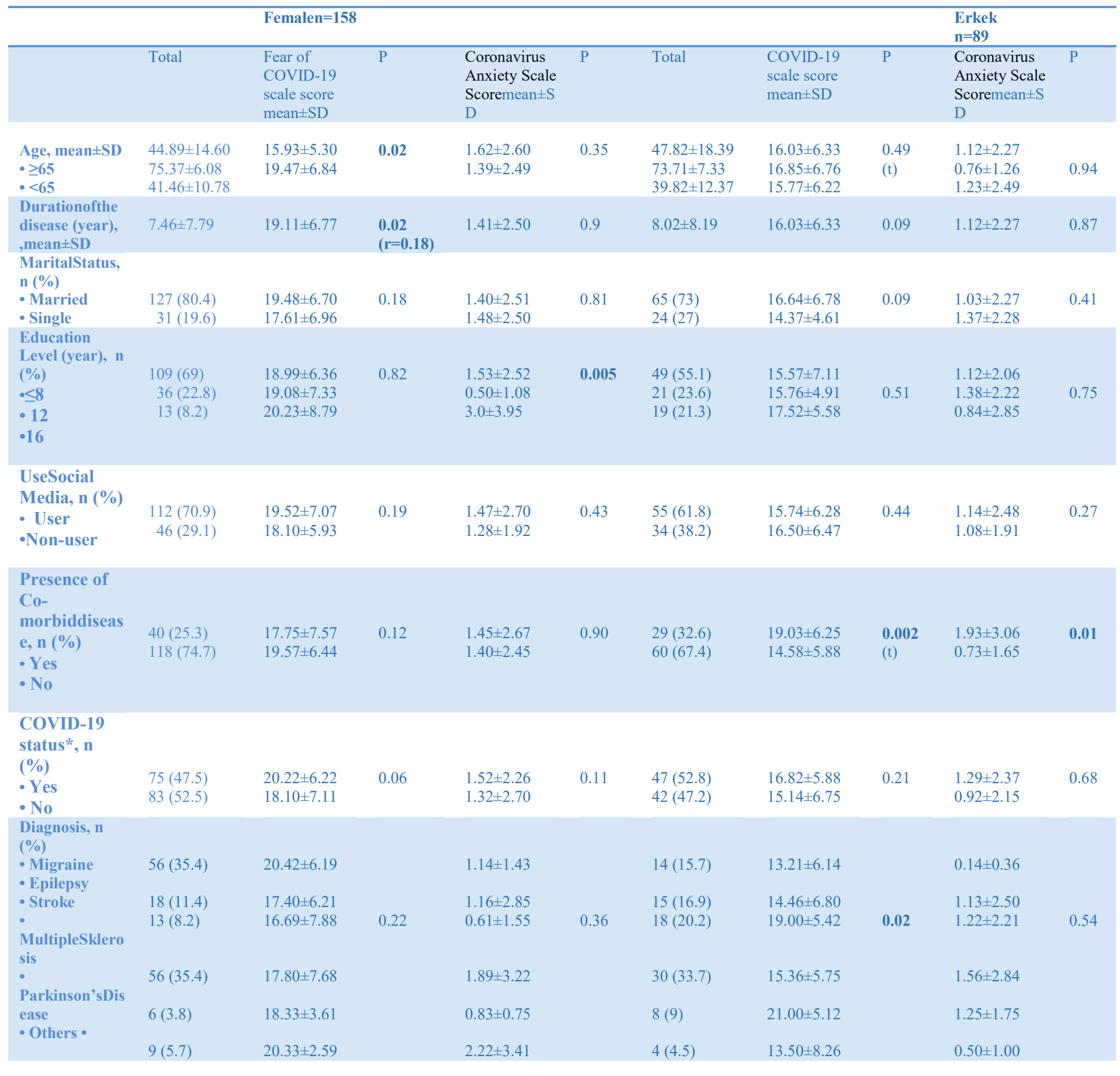


According to the answers given by the participants to survey questions, their characteristics were as follows: $73.2 \%$ of the participants reported that they hesitated to admission to the hospital. The highest rate of hesitating about coming to the hospital was in the migraine group, and the lowest rate was in the MS group ( 80.6 and $62.8 \%$, respectively) (Graphic 1). 37.2\% of participants stated that they were coming for the first time after the beginning of the pandemic. $33.6 \%$ of the participants reported that they regularly came to follow-up visits. About half of this group, who regularly attended follow-up visits, consisted of MS patients. In comparison, 67.6
$\%$ of the participants reported that they are social media users, and $40.2 \%$ of the participants reported that they frequently use it. The highest rate of social media users was in the MS group, and the lowest was in Parkinson's group $(84.53 \%$ and $7.14 \%$, respectively) (Graphic 2). When we asked whether they were affected by the COVID-19 related news they were following on social media, the participants' answers were as follows: $45.67 \%$ affected, $21.86 \%$ not affected $(32.3 \%$ of patients were not evaluated because they were not social media users). The results of the patient groups on this issue were shown in Graphic 3.

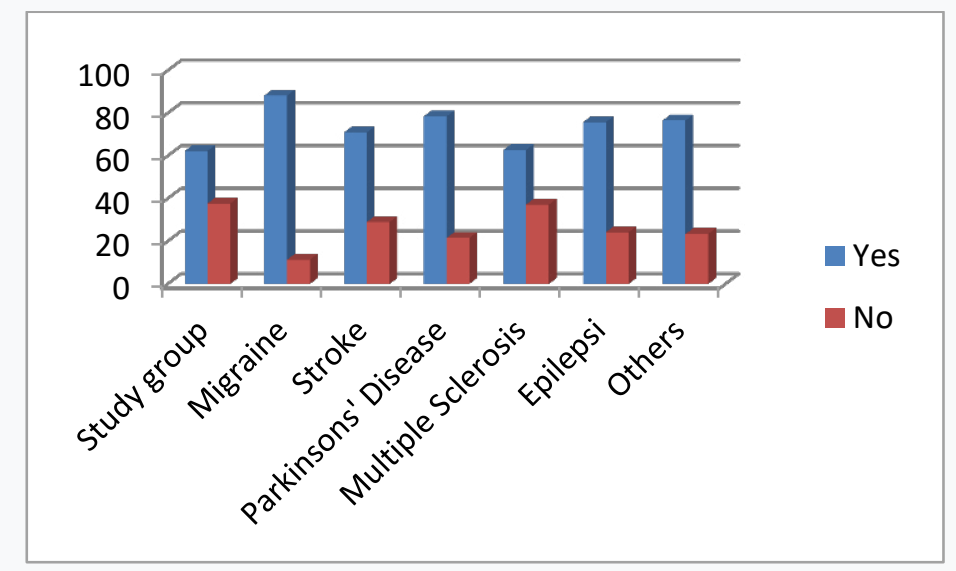

Graphic 1. Status of patients hesitating about admitting to the hospital

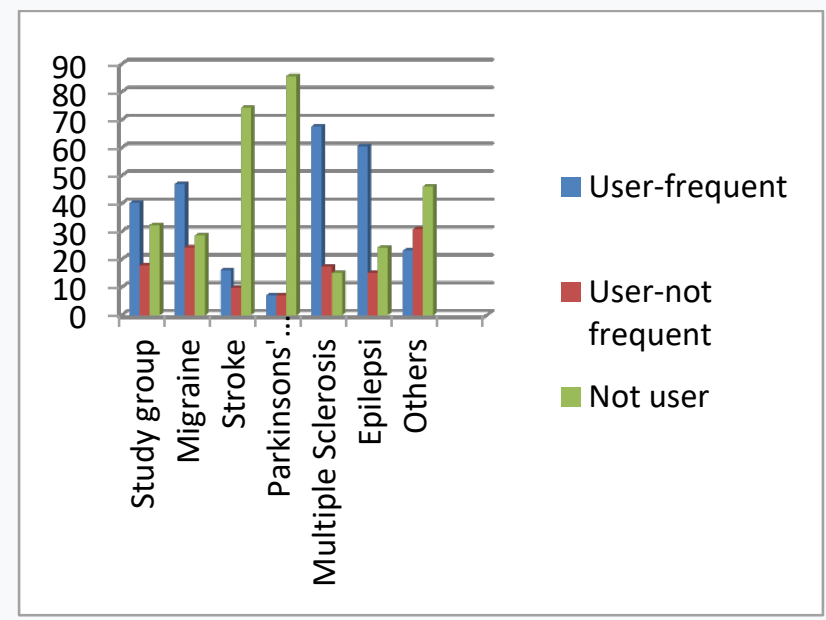

Graphic 2. Status of the patients' use of social media 


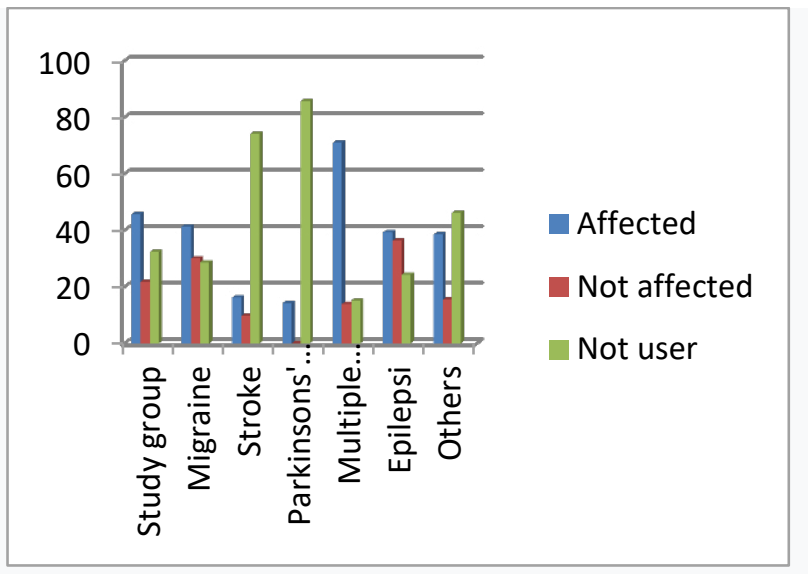

Graphic 3. Status of being affected by the COVID-19 related news they were following on social media

\section{Discussion}

Mental health issues are of great concern during the pandemic. Psychological distress and anxiety were increasingly reported even in the healthy general population (19). This study investigated the fear and anxiety related to COVID-19 in patients with different chronic neurological diseases. We found that the fear and anxiety of COVID-19 levels of the groups were similar. The lowest level of fear of COVID-19 was found in patients with MS (PWMS), and the higher rate of social media use was in the same group. This result is related to patients' high participation in MS social media platforms supported scientifically by MS specialists and the continuation of patient admission to the MS outpatient clinic during the pandemic.

Investigating the relationship between fear of COVID 19 and different demographic and pandemic-related factors, our study demonstrated that females show increased fear than men, and participants younger than 65 showed higher levels of fear. These findings correspond with previous studies, which found the same trend of different emotional distress reactions among male and female participants (20-22). Another study reported that females, younger people, and students were at higher risk of psychological symptoms during the pandemic (23). It is reported that people who were directly or indirectly affected by the pandemic showed fear of illness and death, feeling distressed, loneliness, and depressive symptoms (24). Similarly, our study found FC-19 S scores were statistically significantly higher in those with COVID 19 experience in their family or close circles.

On the other hand, levels of anxiety related to COVID-19 were interestingly low in our study (mean \pm SD: $1.31 \pm 2.42$ ). Although 66.8 $\%$ of the patient answered 'yes' to 'Do you feel worried and anxious during the pandemic compared to the past? We noticed that these patients' expressions were not reflected in their anxiety scores. Only 8 of the patients had scores higher than 9 points stated as the cutoff value for the coronavirus Anxiety Scale (15). Moreover, two of these patients were being followed up at the department of psychiatry with the diagnosis of generalized anxiety disorder. Application of The CAS takes only a few minutes, and as Lee et al. reported, the scale can discriminate dysfunctional anxiety (15). However, CAS is not suitable for evaluating the level of general anxiety related to COVID-19 or pandemic. MS patients are more prone to develop depression and anxiety disorders than healthy populations (25), and it is known that mental health problems can deteriorate their physical disability (26). Although a healthy control group did not exist in our study, the highest CAS scores were recorded in the MS group (Table 1).

In the United Kingdom, strict social distancing is recommended for patients with chronic neurological disease and immunosuppressed patients (27). 
Nevertheless, social distancing or quarantine could have other detrimental effects both mentally and physically on patients requiring physical therapy, mobilization, and assistance because these resources become increasingly challenging to reach (10). When we asked our participants, 'Did you hesitate to addmission to the hospital because of the pandemic?' 75.3 $\%$ of them answered as 'yes. While one-third of the patients stated that they came to the follow-up visit for the first time since the beginning of the pandemic, one-fourth of the patients stated that they came to the follow-up visits regularly at the recommended times. It is reported that some patients have been confronted with difficulties in routine medical treatments because of delayed transportation and shortages of medicines in Italy (28). In our country, since the beginning of the pandemic, the Ministry of Health has allowed patients with chronic diseases to receive their medicines from the pharmacy without a prescription from their doctor (29). Our study, only $4.8 \%$ of the patients stated that they had difficulty obtaining their medicines or could not get them. On the other hand, $29.95 \%$ of the patients reported that the course of their disease worsened because of delayed followup visits.

The communication resources preferred by people to approach information may be influenced by factors such as age, education level, and ability to use communication tools (30). In our study, the mean education level was $53.44 \%$ of the patients had zeight years of education. The MS and epilepsy groups in which found the highest rates of social media use, also had the lowest mean ages. The Parkinson's and stroke groups with a higher average age were also found to have lower rates of social media use compared to other groups.

In recent years, social media has played a crucial role in spreading awareness and knowledge about public health; however, it has also been misused for spreading fake news (31). Kırik and Özkocak reported that the posts of social media users all around the world exceeded 275 million in the period of the first three months of 2020. They stated that the top three countries with the most social media posts about COVID-19 are Japan, the United States, South Korea, and they reported that Turkey was the 11th country with more than 6.5 million social media posts (32). It can be suggested that social media is an essential source of information that is frequently used in terms of risk and crisis communication, especially in terms of access to information (30). While $40.2 \%$ of the patients have been using social media frequently to follow news about COVID-19, $31.9 \%$ of the patients did not use social media at all in our study.

Our study was conducted with face-to-face interviews with patients who came to the outpatient clinic. We could not evaluate patients who were under regular follow up before the pandemic but did not to the outpatient clinic during the pandemic. It can be suggested that we have evaluated those who want to come to the hospital despite the fear and anxiety of COVID.

\section{Conclusion}

Often enough, communication with chronic disease patients by healthcare professionals is a key to promising the patients to be adherence to the medications and manage their disease conditions and positive effects on their mental health. We think that legal regulations regarding using technological tools such as telemedicine and video consultancy should be completed in our country. During the pandemic, the health system needs new solutions. This reduced access to health care can be detrimental to patients with chronic neurological disease. As Telemedicine can be useful in the long-term management of patients with chronic disease, even after pandemics. 


\section{REFERENCES}

1. Huang C, Wang Y, Li X, Ren L, Zhao J, Hu Y I, et al. Clinical features of patients infected with 2019 novel coronavirus in Wuhan, China. The Lance 2020;395: 497-506.

2. WHO (2020). Coronavirus disease (COVID-19) outbreak. https://www.who.int/dg/speec hes/detai 1/who-direc tor-generals-opening-remarks-at-themedia -brief ing-on-covid -19, accessed 11 March 2020.

3. Ministry of Health of Turkish Republic (2020). Turkey daily coronavirus table. https://covid 19.saglik.gov.tr/ accessed 13 April 2020.

4. Arpaci I, Karataş K, Baloğlu M. The development and initial tests for the psychometric properties of the COVID-19 Phobia Scale (C19P-S). Pers Individ Dif. $2020 ; 164: 110108$.

5. Zandifar A, Badrfam R. Iranian mental health during the COVID-19 epidemic. Asian Journal of Psychiatry; 51: 101990.

6. https://covid19.saglik.gov.tr/TR-66393/covid19-salgin-yonetimi-ve-calisma-rehberi.html 22 mart 2021

7. Gazeteci Tekin H, Karaoglu P. Effects of COVID-19 Pandemic on ChildhoodEpilepsy Management; A SurveyStudy. Osmangazi Tip Dergisi;43:318-323.

8. Romagnolo A, Balestrino R, Imbalzano G, Ciccone G, Riccardini F, Artusi CA, et al. Neurological comorbidity and severity of COVID-19. J Neurol. 2021;268:762-769.

9. Roca F, Lang PO, Chassagne P. Chronic neurological disorders and related comorbidities: role of age-associated physiological changes. HandbClin Neurol2019; 167:105-122.

10. Bhaskar S, Bradley S, Israeli-Korn S, Menon $\mathrm{B}$, Chattu VK, Thomas $\mathrm{P}$, et al. Chronic Neurology in COVID-19 Era: Clinical Considerations and Recommendations From the REPROGRAM Consortium. Front Neurol 2020;11:664.

11. Ahorsu DK, Lin C, Imani V, Saffari M, Griffiths MD, Pakpour A H. The fear of COVID-19 scale: Development and initial validation. International Journal of Mental Health and Addiction 2020;

12. Lin C Y. Social reaction toward the 2019 novel coronavirus (COVID-19). Social Health and Behavior 2020; 3:1-2.

13. Bakioglu F, Korkmaz O, Ercan H. Fear of COVID-19 and positivity: Mediating role of intolerance of uncertainty, depression, anxiety, and stress. International Journal of Mental Health and Addiction 2020.

14. Satici B, GocetTekin E, Deniz M E, Satici SA. Adaptation of the Fear of COVID-19 Scale: Its association with psychological distress and life satisfaction in Turkey. International Journal of Mental Health and Addiction 2020.

15. Lee SA. Coronavirus Anxiety Scale: A brief mental health screener for COVID-19 related anxiety. Death Studies 2020;44: 393-401.

16. Evren C, Evren B, Dalbudak E, Topcu M, Kutlu N. Measuring anxiety related to COVID-19: A
Turkish validation study of the CoronavirusAnxiety Scale. Death Studies 2020.

17. Bicer İ, Cakmak C, Demir H, Kurt M. KoronavirüsAnksiyeteÖlçeğiKısaFormu: TürkçeGeçerlikveGüvenirlikÇalışması. Anatolian Clinic the Journal of Medical Sciences (COVID 19 ÖzelSayıs1) 2020;25: 216-225 .

18. Sayık D, Yigit D, Acıkgöz A, Colak E, Mumcu O. Turkish Validity and Reliability of the Corona virüs Anxiety Scale. Eskisehir Med J 2021;2:1622.

19. Serafini G, Parmigiani B, Amerio A, Aguglia A, Sher L, Amore M. The psychological impact of COVID-19 on the mental health in the general population. QJM. 2020;113:531-7.

20. Limcaoco RSG, Mateos EM, Fernandez JM, Roncero C. Anxiety, worry and perceived stress in the world due to the COVID-19 pandemic, Preliminary Results. medRxiv 2020.

21. Qiu J, Shen B, Zhao M, Wang Z, Xie B, Xu Y. A nationwide survey of psychological distress among Chinese people in the COVID-19 epidemic: implications and policy recommendations. Gen. Psychiatry 2020; 33: e100213.

22. Sakib N, Bhuiyan AKMI, Hossain S, Al Mamun F, Hosen I, et al. Psychometric Validation of the Bangla Fear of COVID-19 Scale: Confirmatory Factor Analysis and Rasch Analysis. Int J Ment Health Addict. 2020;11:1-12.

23. Balsamo $M \&$ Carlucci L. Italians on the age of COVID-19:The self-reported depressive symptoms through web-based survey. Frontiers in Psychology 2020;569276.

24. International Federation of Red Cross and Red Crescent Societies (IFRC). (2020). Mental health and psychosocial support for staff, volunteers and communities in an outbreak of novel coronavirus. https://pscentre.org/wpcontent/uploads/2020/02/MHPSS-in-nCoV2020 ENG-1.pdf (accessed 29 May 2020).

25. Beiske A, Svensson E, Sandanger I, Czujko B, Pedersen E, Aarseth J, et al. Depression and anxiety amongst multiple sclerosis patients. European journal of neurology 2008;15: 239-245.

26. Marrie RA, Reingold S, Cohen J, Stuve O, Trojano M, Sorensen PS, Cutter G, Reider N. The incidence and prevalence of psychiatric disorders in multiple sclerosis: a systematic review. Mult Scler. 2015;21:305-17.

27. Public Health England. Guidance on social distancing for everyone in the UK. (2020). Available online at: https://www.gov.uk/government/publications/covi d-19-guidance-on-social-distancing-and-forvulnerable-people/guidance-on-social-distancingfor-everyone-in-the-uk-and-protectingolderpeople-and-vulnerable-adults(accesed April5,2020)

28. Pellino G, Spinelli A. How COVID-19 outbreak is impacting colorectal cancer patients in Italy: a long shadow beyond infection. Dis. Colon Rectum 2020 . 
29. https://www.titck.gov.tr/duyuru

30. Hosgor H, Akozlu Z, Gunduz D. The perception concerning the COVID-19 pandemic: case of Turkey . The European Research Journal 2021;7:116-126

31. Depoux A, Martin S, Karafillakis E, Preet R, Wilder-Smith A, Larson $\mathrm{H}$. The pandemic of social media panic travels faster than the COVID-19 outbreak. J Travel Med. 2020 18;27:taaa031.

32. Özkoçak V, KırıkAM. Social media and new coronavirus (Covid-19) pandemia in the context of the new world order. J SocSci 2020;45:133-54. [Article in Turkish] 